\author{
Joanna Lizińska* \\ Leszek Czapiewski**
}

\title{
REASSESSING POLISH IPO \\ UNDERPRICING AND UNDERPERFORMANCE
}

\begin{abstract}
The purpose of the research was to assess the price behavior of initial public offerings (IPO) of equities listed on the Warsaw Stock Exchange from 1996 to 2010. We also aimed to observe IPO underpricing and the underperformance phenomenon with different approaches. Short-term performance was analyzed with raw and adjusted initial returns. For the long-term, abnormal returns were compounded and cumulated. Different methods of outliers detection and ways of minimizing the detrimental effect of outliers were applied. In long-term studies, we also compared the results for the daily, weekly and monthly returns. IPO underpricing and underperformance on the WSE still remains substantial and significant, even accounting for the variety of methods applied. The difference in underpricing between the 1996-2004 and the 2005-2010 sample was insignificant. However, we reported statistically significant and economically important differences in underperformance between both samples.
\end{abstract}

Key words: IPO, underpricing, underperformance.

\section{INTRODUCTION}

The Warsaw Stock Exchange (WSE) has been one of the most dynamically developing European markets for several years. It has been an unquestionable leader in Central and Eastern Europe in terms of key market indicators, such as market capitalization, volume and number of initial public offerings (IPO). It makes the Polish stock exchange an interesting and important research area.

A substantial body of literature has examined the initial underpricing and long-term underperformance. These intriguing areas in finance research have been well documented throughout world markets [Ritter 2003, among many others]. Although the US-centered empirical studies do not dominate as much now as in the past, empirical works covering emerging markets are still insufficient, which is especially true for the years covering the latest financial market turbulences.

\footnotetext{
* Ph.D., Poznan University of Economics, Department of Corporate Finance.

** Ph.D., Poznan University of Economics, Department of Corporate Finance.
} 
The aim of this study is to update the results of the short- and long-term price behavior of the securities of IPO firms that were listed on the Warsaw Stock Exchange, with a sample covering the period from 1996 to 2010. Additionally, the underpricing and underperformance phenomenon was analyzed with different research approaches. It will make comparisons with the results of other studies more accurate, as the methods that have been applied to date differed to a large extent. Raw and adjusted initial returns were calculated to observe short-term returns. Long-term performance was observed with the compounding and cumulating of abnormal returns up to the third IPO anniversary. For both research horizons, we applied two different methods of outliers detection and two different ways of minimizing the detrimental effect of possibly spurious outliers. In long-term studies, the daily, weekly and monthly returns of securities and market indexes were used.

There have been several studies covering initial public offers on the Polish stock exchange. The studies by Aussenegg [2000], Jelic and Briston [2003], Lyn and Zychowicz [2003] documented IPO price behavior for the first stage of WSE development and the latest two studies concentrated mainly on privatization issues. Aussenegg [2000] analyzed IPOs from the first nine years after the reopening of the Warsaw Stock Exchange in 1991. He reported raw and WIG-adjusted initial returns of 38.5 percent and 33.1 percent, respectively. The mean (median) market-adjusted three-year IPO returns were equal to 11.5 (-61.1) percent. Lyn and Zychowicz [2003] documented underpricing of 54.5 percent for Polish IPOs from 1991 to 1998. They did not find significant evidence for underperformance for the third year after offering. Jelic and Briston [2003] examined IPOs during 1991-1999, documenting the mean market-adjusted initial return to be equal to 27.37 percent, a mean cumulative abnormal return of -37.8 percent and mean abnormal buy-and-hold return for the three-year period of -26.5 percent.

More recent studies on Polish IPOs include Czapiewski et al. [2010], Jewartowski and Lizińska [2012], Cornanic and Novak [2013] and Czapiewski and Lizińska [2014]. Jewartowski and Lizińska [2012] used a more recent sample of Polish IPOs from 1998 to 2008 and reported a mean (median) underpricing of 14.0 (6.3) percent. They also observed long-term buy-and-hold three-year abnormal returns at the level of -22.6 percent (median -44.5). Cornanic and Novak [2013] updated the results for the underpricing level by extending the sample period to 2009, as it covered the five-year period from 2005 to 2009 . They showed the mean underpricing to be equal to 15.7 percent as measured with mean initial WIG-adjusted returns with Winsorizing at the 1 percent level (17.4 percent without Winsorization).

The most recent study covering long-term IPO performance was presented by Czapiewski and Lizińska [2014] for the sample of 2004-2009. The mean (median) buy-and-hold abnormal returns at the third IPO anniversary totaled 
-7.1 (-24.9) percent. The buy-and-hold returns for each IPO and the reference portfolio returns were Winsorized at the 3 percent level. They also reported the underpricing level with the mean (median) raw initial returns equal to 11.0 (6.9) percent and mean (median) WIG-adjusted initial returns equal to 10.9 (6.54) percent. Czapiewski et al. [2012] concentrated only on short-term performance. The paper documented mean (median) initial WIG-adjusted returns of 34.1 percent (14.0) for IPOs from 1991 to 2000 and a mean (median) of 13.5 (5.5) percent for 2001-2011. It is the most recent research on underpricing, but there was no method of outliers problem solving applied.

This paper was supported by the National Science Centre as a research project (2011/01/B/HS4/02361).

The paper proceeds as follows. In section 2 we describe the dataset and discuss the method details for the empirical investigation. The results of the average underpricing level are presented in section 3. Section 4 reports the differences in initial returns for subperiods. Section 5 and 6 report the level of underperformance and its changes with time, respectively. The last section summarizes and concludes.

\section{DATA, METHODOLOGY AND SAMPLE DESCRIPTION}

The source for the IPO and related data was Notoria Serwis, Ceduła, the official site of the WSE [http://www.gpw.pl/] and www.gpwinfostrefa.pl. The first step was to prepare the authors' own database of close prices for all companies listed on the WSE, including the necessary adjustments such as splits, preemptive rights and dividends.

The main sample consists of 354 IPOs offered from 1996 to 2010 on the Polish main stock market, the Warsaw Stock Exchange (WSE). We eliminated the most recent IPO data from the last three years in order to achieve the same research sample for the short-term and three-year returns. The sample includes only IPOs that were connected with the issuance of new common stock without prior trading history on alternative markets. The data for initial public offerings, stock prices and index values were not always uniform and comprehensive, so some limitations had to be put in the later research. Table 1 provides a sample description with a few main firm characteristics for the year before the IPO date.

The Polish equity market has changed rapidly during the fifteen years of the sample period. The first eight years represented a stable period without extraordinary long-term market down- or upturns. The period from 2004 to the first half of 2007 represented the bull market. After the market peak, a huge equity price fall was observed up to the end of 2009. The financial crisis was accompanied by a considerable drop in IPO activity in 2008 and 2009. 
Following this there was a positive change in investor sentiment, reflected in the higher level of equity prices. However, IPO activity remained weak up to the end of the sample period in 2010. Figure 1 plots the quarterly mean values of the WIG Index (the main Polish WSE index) with the quarterly number of IPOs.

Table 1. Descriptive statistics

\begin{tabular}{lrrrrr}
\hline & $\begin{array}{c}\text { Assets [PLN } \\
\text { thousand] }\end{array}$ & $\begin{array}{c}\text { Sales [PLN } \\
\text { thousand] }\end{array}$ & $\begin{array}{c}\text { Return } \\
\text { on assets [\%] }\end{array}$ & $\begin{array}{c}\text { Return } \\
\text { on equity [\%] }\end{array}$ & $\begin{array}{c}\text { Leverage } \\
\text { [\%] }\end{array}$ \\
\hline Mean & 1349979 & 589935 & $9 \%$ & $23 \%$ & $9 \%$ \\
Median & 62462 & 91882 & $8 \%$ & $19 \%$ & $4 \%$ \\
Minimum & 292 & 548 & $-48 \%$ & $-74 \%$ & $0 \%$ \\
Maximum & 84568065 & 19408706 & $82 \%$ & $308 \%$ & $78 \%$ \\
Number of valid cases & 293 & 293 & 293 & 289 & 289 \\
\hline
\end{tabular}

Source: own calculations.

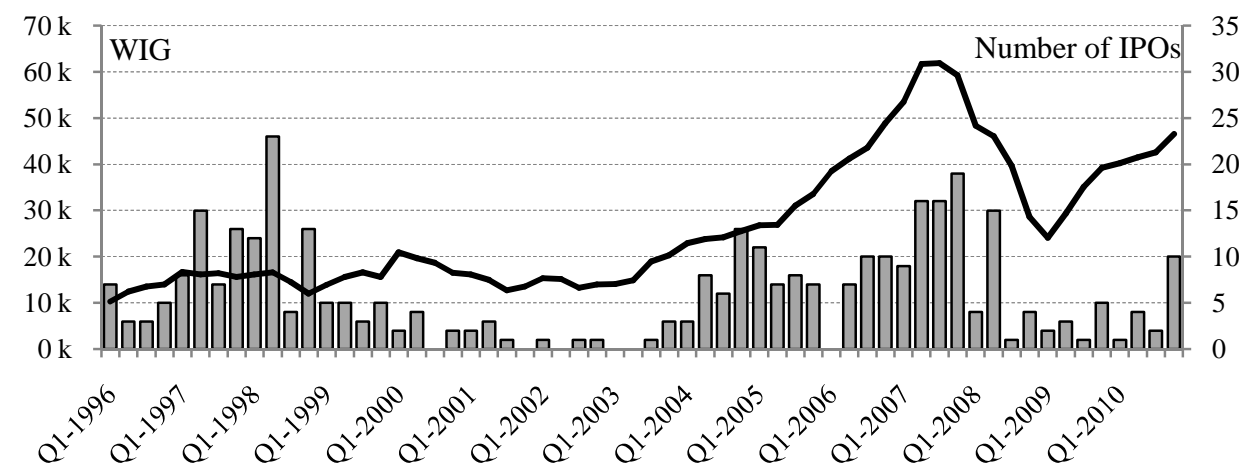

Figure 1. IPO activity and the WIG index

Source: own calculations.

IPO initial return was defined as the percentage change between the offer price and the first closing market price of the IPO, which was expressed as:

$$
I R_{i, t}=\frac{I P_{i}}{P O_{i}}-1
$$

where; $I P_{i}$ is the first aftermarket price for IPO $i$ and $P O_{i}$ is the offer price for IPO $i$.

After this, we adjusted raw initial returns by the market return using WIG index. 
Next, we calculated buy-and-hold abnormal returns ( $B H A R$ ) to observe the long-term IPO price behavior. We estimated BHARs with the use of daily, weekly and monthly returns. The weekly and monthly returns were reported as the last return in the given week or month, respectively. The buy-and-hold return for IPO $i\left(B H R_{i, T}\right)$ was defined as:

$$
B H R_{i . T}=\prod_{t=1}^{T}\left(1+R_{i, t}\right)-1
$$

where; $R_{i, t}$ was the return in session $t$, and $T$ was the aftermarket trading session number. For daily returns, it was assumed that a year was equivalent to 251 trading days. For weekly returns, there were 52 weeks in each year. For monthly returns, it was assumed that each year was equal to 12 months. The buy-and-hold return for the corresponding WIG-based reference portfolio for IPO $i\left(B H R_{i, T}^{W I G}\right)$ was defined as:

$$
B H R_{i . T}^{W I G}=\prod_{t=1}^{T}\left(1+R_{i, t}^{W I G}\right)-1
$$

where; $R_{i, t}^{W I G}$ was the WIG return in session $t$.

The buy-and-hold abnormal return for each IPO $i\left(B H A R_{i, T}\right)$ was given by:

$$
B H A R_{i, T}=B H R_{i, T}-B H R_{i, T}^{W I G}
$$

An alternative performance measure, the cumulative abnormal return ( CAR ) was employed afterwards. The general formula for the abnormal market adjusted return $\left(A R_{i, t}\right)$ for each IPO $i$ for $t$ session was expressed as:

$$
A R_{i, t}=R_{i, t}-R_{i, t}^{W I G}
$$

The abnormal returns $\left(A R_{i, t}\right)$ were cumulated to get cumulative abnormal returns $\left(C A R_{i, T}\right)$.

The buy-and-hold abnormal returns were the main measure of long-term performance. They were applied to simulate a real trading situation of an investment in securities at the IPO date, holding it for a period of time and later selling it. The cumulative abnormal returns were only complementary to buy-and-hold abnormal returns because of the rebalancing bias.

Two methods of minimizing the detrimental effect of extreme outliers were employed. First, the censoring method of Winsorization (W) was applied. Additionally, we excluded the possibly spurious outliers by trimming (T). Methods of finding outliers in data were also differentiated. First, with the use of 
the interquartile range $(I Q R)$, we found outliers as the observations that fell below $Q 1-1.5 \cdot I Q R$ or above $Q 3+1.5 \cdot I Q R(\mathrm{Q})$. Second, the lower and upper bounds were calculated as the mean minus 1.5 times the standard deviation and the mean plus 1.5 times the standard deviation, which was later called the standard deviation approach (S). As a result, four combinations of detection and treatment of possible outliers has been applied (W-Q, W-S, T-Q, T-S).

Next, we tested the null hypothesis that the average raw initial return (initial adjusted return, buy-and-hold abnormal return, cumulative abnormal return, respectively) was equal to zero. The parametric Student t-test and the non-parametric Wilcoxon signed-rank test were employed.

In the final research step, the sample period of 1996-2010 was divided into two subperiods of nearly equal IPO numbers. The years from 1996 to 2004 represented the mostly stable market (Sample I, S I). The second period, from 2005 to 2010, included rapid changes of investor sentiment (Sample II, S II). This part of the research contains results for the daily data. We tested the differences in short- and long-term returns between the subsamples with the Student t-test and the Mann-Whitney U-test. Conventional confidence levels $(1 \%, 5 \%$ and $10 \%)$ were set to test the significance.

\section{INITIAL RETURNS}

A summary representation of raw and WIG-adjusted initial returns for the whole sample is given in Table 2.

Table 2. Initial returns

\begin{tabular}{|c|c|c|c|c|c|c|c|c|}
\hline & \multicolumn{4}{|c|}{ Raw initial returns } & \multicolumn{4}{|c|}{ Adjusted initial returns } \\
\hline & $\mathrm{W}-\mathrm{Q}$ & $\mathrm{W}-\mathrm{S}$ & $\mathrm{T}-\mathrm{Q}$ & $\mathrm{T}-\mathrm{S}$ & $\mathrm{W}-\mathrm{Q}$ & $\mathrm{W}-\mathrm{S}$ & $\mathrm{T}-\mathrm{Q}$ & $\mathrm{T}-\mathrm{S}$ \\
\hline Mean [\%] & 13.46 & 15.63 & 8.80 & 12.49 & 13.51 & 15.56 & 9.25 & 12.20 \\
\hline Median [\%] & 9.49 & 9.49 & 6.00 & 7.29 & 9.07 & 9.07 & 6.50 & 6.86 \\
\hline Std $[\%]$ & 22.88 & 28.68 & 16.40 & 23.42 & 23.22 & 28.58 & 17.35 & 23.00 \\
\hline Skewness & 0.56 & 1.03 & 0.63 & 1.04 & 0.56 & 1.03 & 0.70 & 1.02 \\
\hline Kurtosis & -0.17 & 1.07 & 0.63 & 1.64 & -0.10 & 1.07 & 0.75 & 1.61 \\
\hline p-val & 0.0000 & 0.0000 & 0.0000 & 0.0000 & 0.0000 & 0.0000 & 0.0000 & 0.0000 \\
\hline (t-Stud) & $* * *$ & $* * *$ & $* * *$ & $* * *$ & $* * *$ & $* * *$ & $* * *$ & $* * *$ \\
\hline p-val & 0.0000 & 0.0000 & 0.0000 & 0.0000 & 0.0000 & 0.0000 & 0.0000 & 0.0000 \\
\hline (Wilcoxon) & $* * *$ & $* * *$ & $* * *$ & $* * *$ & $* * *$ & $* * *$ & $* * *$ & $* * *$ \\
\hline $\mathrm{N}$ & 354 & 354 & 307 & 334 & 354 & 354 & 312 & 333 \\
\hline
\end{tabular}

Notes: Significance at the 1 percent $(* * *)$ level. Methods of outliers treatment: Winsorization with interquartile range use (W-Q), Winsorization with the standard deviation approach (W-S), trimming with interquartile range use $(\mathrm{T}-\mathrm{Q})$, trimming with the standard deviation approach $(\mathrm{T}-\mathrm{S})$.

Source: own calculations. 
The average level of raw and market-adjusted first-day returns was highly differentiated according to the method selected. The mean (median) raw returns ranged from 8.8 (6.00) percent for trimming based on the interquartile range (T-Q approach), up to 15.63 (9.49) percent for Winsorizing based on the standard deviation approach (W-S). The adjusted initial returns were slightly less differentiated, with 9.25 (6.50) percent to 15.56 (9.07) percent for the T-Q and $\mathrm{W}-\mathrm{S}$ approach, respectively. However, all of the initial returns were positive and economically and statistically significant, regardless of the method.

\section{THE CHANGING UNDERPRICING LEVEL WITH TIME}

In this section, we investigated whether differences in the average level of underpricing did exist between IPOs from the early period after the reopening the WSE and the later years covering the rapid changes in capital markets worldwide. The differences in average raw and adjusted initial returns are shown in Table 3.

Table 3. Initial returns for subperiods

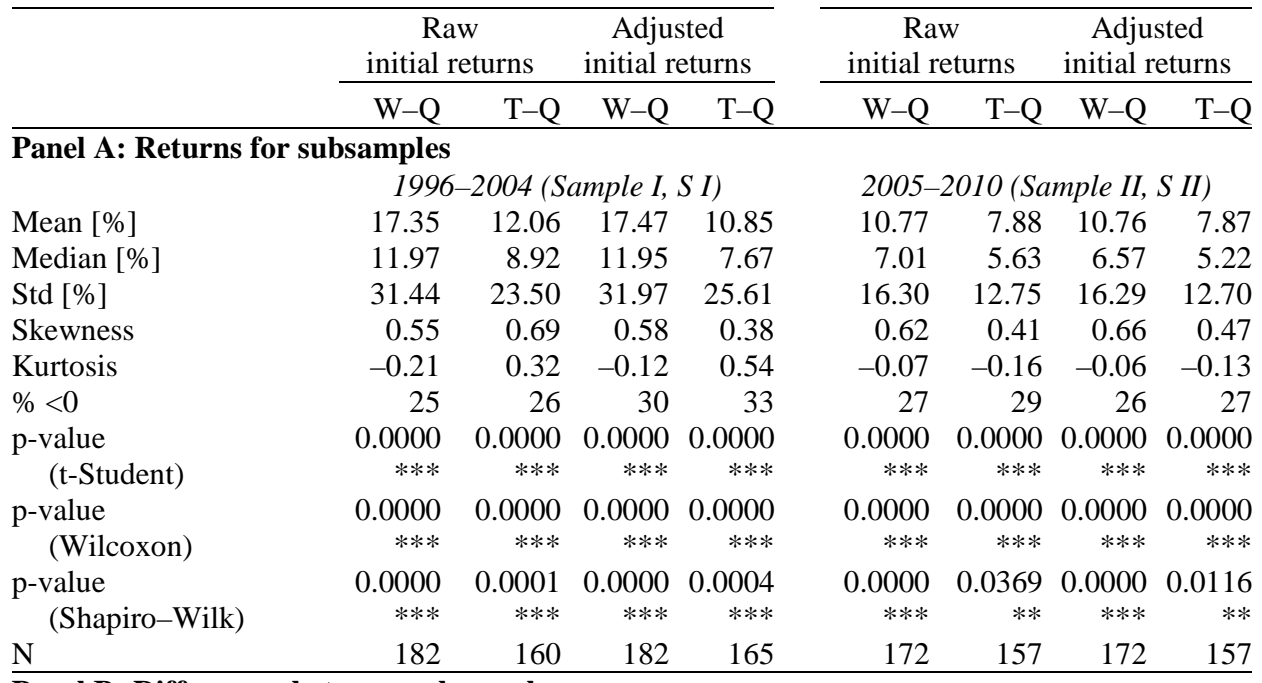

Panel B: Differences between subsamples

$\begin{array}{lrrrr} & S I / S \text { II } & \text { S I/S II } & \text { S I/S II } & \text { S I/S II } \\ \text { p-value } & 0.0132 & 0.0497 & 0.0127 & 0.1835 \\ \quad \text { (t-Student, diff.) } & * * & * * & * * & \\ \begin{array}{c}\text { p-value } \\ \text { (Mann-Whitney) }\end{array} & 0.2197 & 0.3554 & 0.2396 & 0.5735\end{array}$

Notes: Significance at the 1 percent $(* * *)$ and 5 percent $(* *)$ level. Methods of outliers treatment: Winsorization with interquartile range use (W-Q), Winsorization with the standard deviation approach $(\mathrm{W}-\mathrm{S})$, trimming with interquartile range use $(\mathrm{T}-\mathrm{Q})$, trimming with the standard deviation approach (T-S).

Source: own calculations. 
The differences in underpricing level reported for both subsamples were economically significant, as the mean (median) initial return reported for 1996 -2004 (S I) were from 3 (2.5) to almost 7 (5.0) percent points higher than in the later period (S II). However, the differences were not statistically significant, as indicated by the Mann-Whitney non-parametric U-test.

\section{LONG-TERM RETURNS}

Long-term price behavior was examined using the daily, weekly and monthly data. They were applied into the buy-and-hold and cumulative abnormal returns estimation. The results of the IPO performance investigation up to the third year after first public issuance with the use of daily, weekly and monthly data are reported in Table 4, Table 5 and Table 6 , respectively.

The research confirmed that negative IPO long-term returns were either statistically or economically significant for each of the methods of abnormal returns calculation. However, its level appeared to be very sensitive to the method of choice.
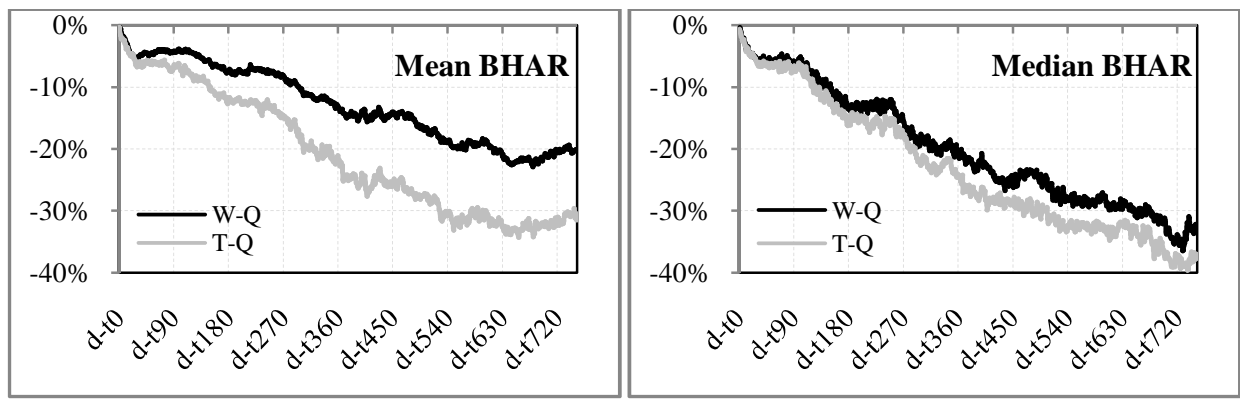

Figure 2. IPO buy-and-hold abnormal returns

Source: own calculations.
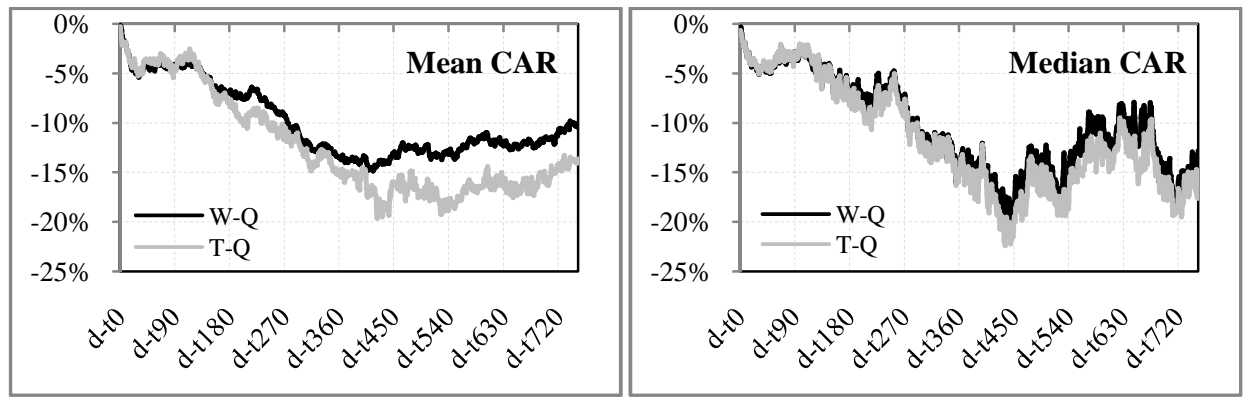

Figure 3. IPO cumulative abnormal returns

Source: own calculations. 


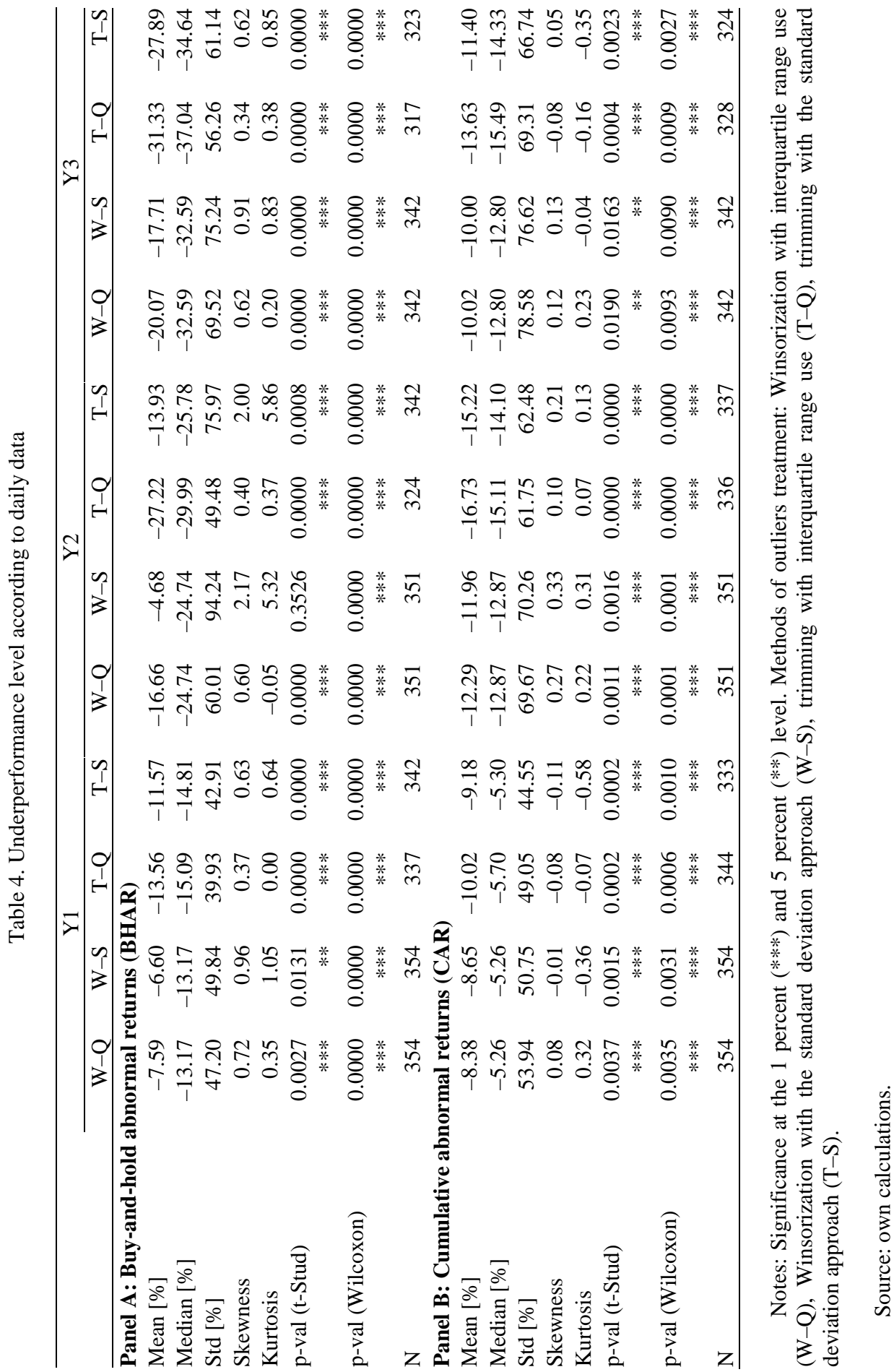




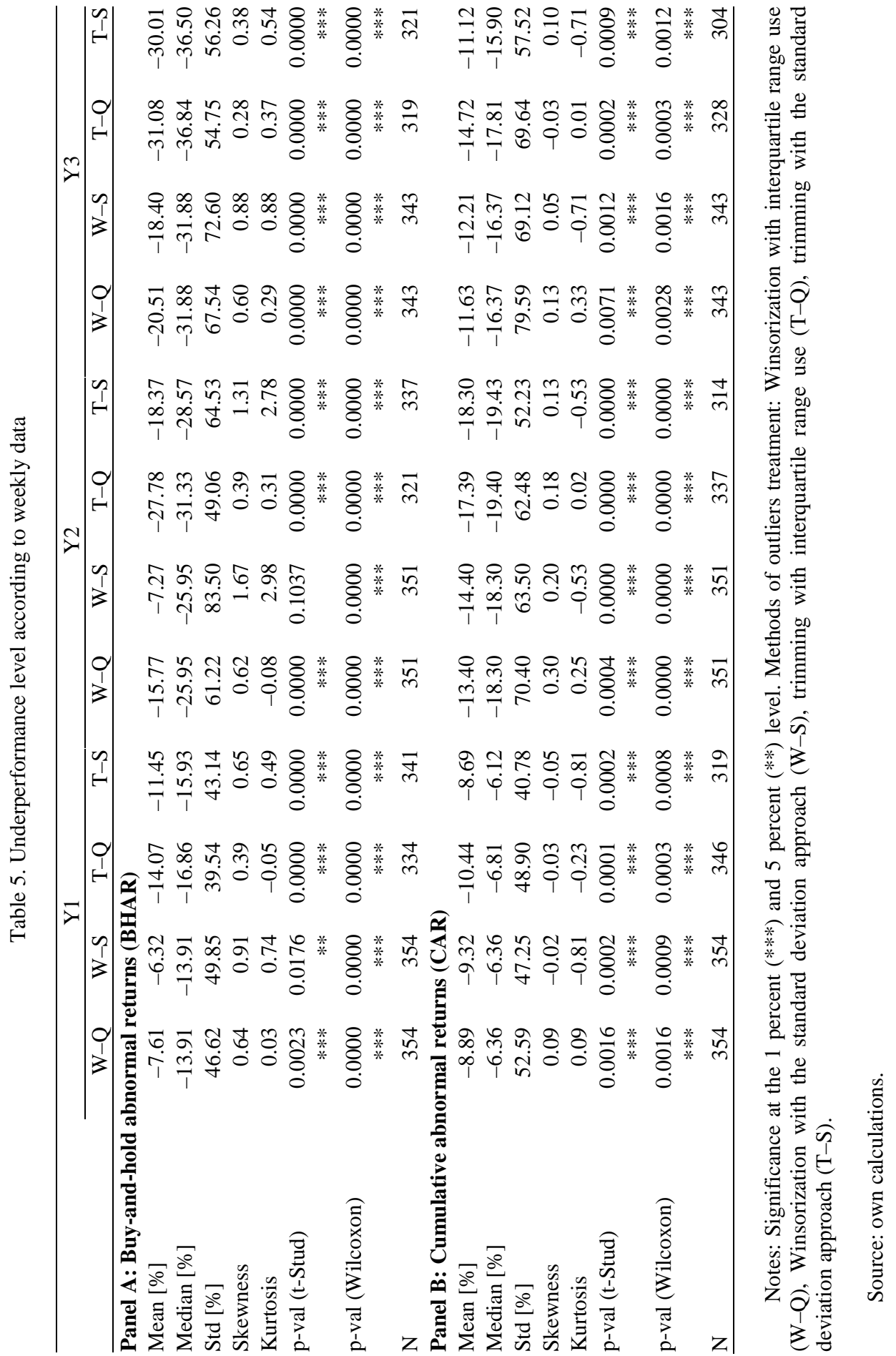




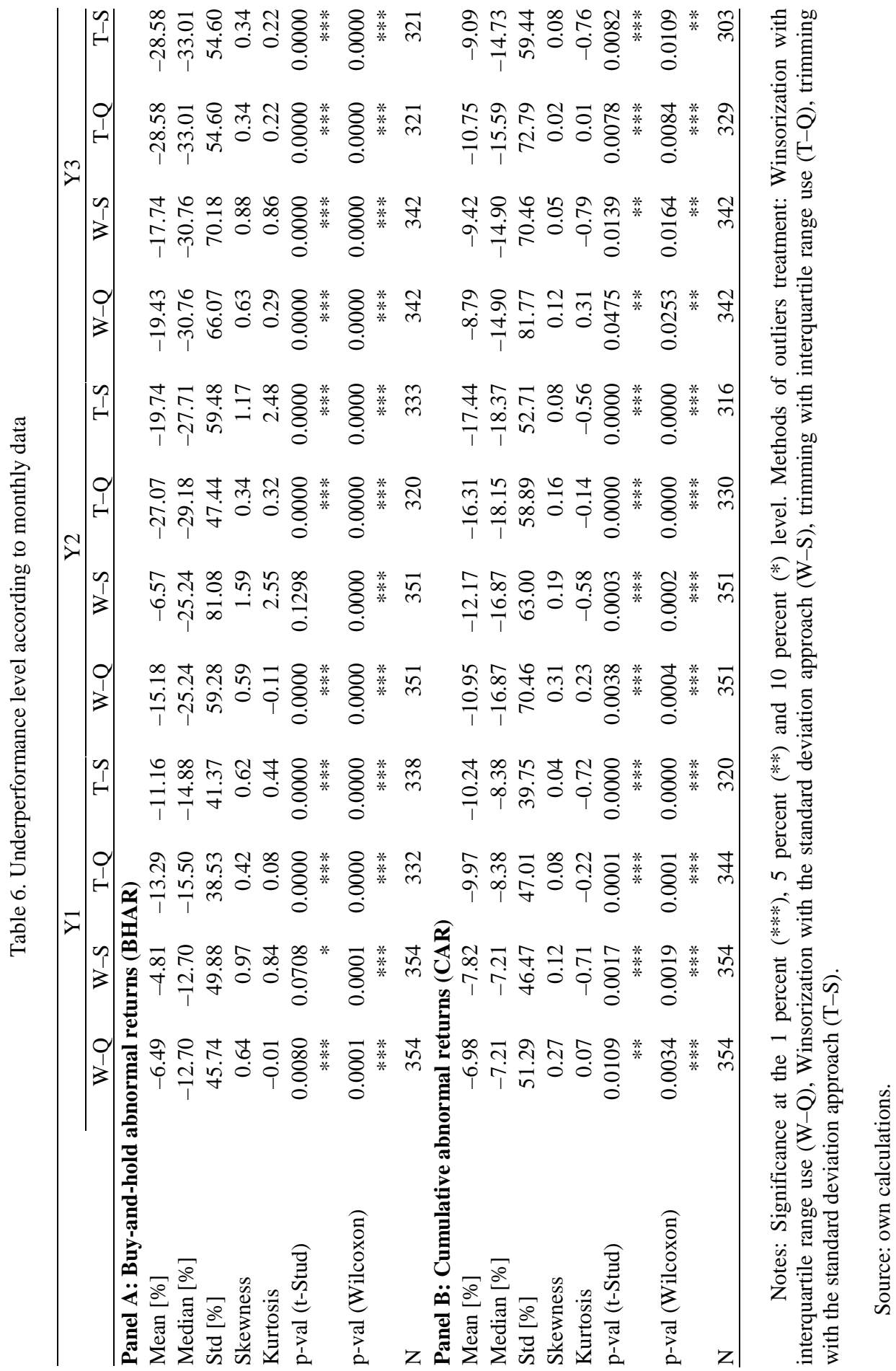


To illustrate, the highest three-year mean BHAR was reported for the daily data with Winsorizing with the standard deviation approach $(-17.71)$ and the most severe underperformance was reported also for daily data but with outliers trimming and the interquartile range application $(-31.33)$. The extreme values were not so distinct for medians but they still differed by more than six percentage points $(-30.76$ vs. -37.04$)$.

Figure 2 and Figure 3 show mean and median long-term WIG-adjusted returns up the third IPO anniversary. The four charts illustrate long-term IPO performance calculated with the Winsorized and trimmed daily data, with the interquartile range used for outliers detection.

\section{THE CHANGING UNDERPERFORMANCE LEVEL}

The objective of this section was to compare the underperformance level between two subsamples. The results for the daily data with outliers detection based on the interquartile range are detailed in Table 7.

Table 7. Initial returns

\begin{tabular}{|c|c|c|c|c|c|c|c|c|}
\hline & \multicolumn{4}{|c|}{ Raw initial returns } & \multicolumn{4}{|c|}{ Adjusted initial returns } \\
\hline & $\mathrm{W}-\mathrm{Q}$ & $\mathrm{W}-\mathrm{S}$ & $\mathrm{T}-\mathrm{Q}$ & $\mathrm{T}-\mathrm{S}$ & $\mathrm{W}-\mathrm{Q}$ & $\mathrm{W}-\mathrm{S}$ & $\mathrm{T}-\mathrm{Q}$ & $\mathrm{T}-\mathrm{S}$ \\
\hline Mean [\%] & 13.46 & 15.63 & 8.80 & 12.49 & 13.51 & 15.56 & 9.25 & 12.20 \\
\hline Median [\%] & 9.49 & 9.49 & 6.00 & 7.29 & 9.07 & 9.07 & 6.50 & 6.86 \\
\hline Std [\%] & 22.88 & 28.68 & 16.40 & 23.42 & 23.22 & 28.58 & 17.35 & 23.00 \\
\hline Skewness & 0.56 & 1.03 & 0.63 & 1.04 & 0.56 & 1.03 & 0.70 & 1.02 \\
\hline Kurtosis & -0.17 & 1.07 & 0.63 & 1.64 & -0.10 & 1.07 & 0.75 & 1.61 \\
\hline p-val & 0.0000 & 0.0000 & 0.0000 & 0.0000 & 0.0000 & 0.0000 & 0.0000 & 0.0000 \\
\hline (t-Stud) & $* * *$ & $* * *$ & $* * *$ & $* * *$ & $* * *$ & *** & $* * *$ & $* * *$ \\
\hline p-val & 0.0000 & 0.0000 & 0.0000 & 0.0000 & 0.0000 & 0.0000 & 0.0000 & 0.0000 \\
\hline (Wilcoxon) & $* * *$ & $* * *$ & $* * *$ & $* * *$ & $* * *$ & $* * *$ & $* * *$ & $* * *$ \\
\hline $\mathrm{N}$ & 354 & 354 & 307 & 334 & 354 & 354 & 312 & 333 \\
\hline
\end{tabular}

Notes: Significance at the 1 percent $(* * *)$ level. Methods of outliers treatment: Winsorization with interquartile range use (W-Q), Winsorization with the standard deviation approach (W-S), trimming with interquartile range use (T-Q), trimming with the standard deviation approach (T-S).

Source: own calculations.

The level of underperformance reported in the subperiods were strongly dependent on the method chosen. The mean and median level of long-term underperformance was more severe during the first sample period. In terms of underperformance, on the third IPO anniversary the returns were lower 24.31 and 27.44 percentage points in terms of medians for Winsorizing and trimming, respectively. The differences in long-term price behavior in different periods appears to be statistically significant and economically important. 


\section{CONCLUSION}

This study has examined the price behavior of initial public offerings (IPO) of equities listed on the Warsaw Stock Exchange (WSE) during the period from 1996 to 2010. The sample period encompassed rapid changes on the Polish financial market and IPO activity fluctuated substantially. There were quarters with no new listing and - in contrast - there were quarters with over a dozen (up to 23) IPOs.

The empirical analysis performed in the study documented that IPO underpricing on the WSE remained substantial and significant, even accounting for the variety of methods applied. Further, the long-term abnormal returns were strongly negative and statistically significant, which accentuated the importance of the problem for market participants.

Our study revealed that differences in the underpricing level between IPOs during the period of 1996-2004 and 2005-2010 appears to be insignificant. However, we reported statistically significant and economically important differences in the long-term underperformance level for both samples covering the subperiods, with much higher returns for the more recent sample.

IPO anomaly has absorbed academics and investors, as they have been fascinated to discover results inconsistent with accepted asset pricing models. It still seems that the puzzling price behavior of IPOs cannot be said to be illusory, or not robust to the methodology, sample or period of choice. The empirical results provided evidence that as well as the short-term underpricing, the long-term underperformance level for the Warsaw Stock Exchange remained statistically and economically important in the period under review. However, we leave the question open of whether the observed anomalous returns are not a manifestation of a more systematic return pattern in the capital market. Although the methods used in the current research were quite wide, the empirical investigation should be continued in order to control better the risk for IPO companies. It would make the conclusions more attractive for market participants.

\section{REFERENCES}

Aussenegg W., 2000, Privatization Versus Private Sector Initial Public Offerings in Poland, Multinational Finance Journal 4(1-2), 69-99.

Cornanic A., Novak J., 2013, Signaling by Underpricing the Initial Public Offerings of Primary Listings in an Emerging Market, Available at SSRN: http://ssrn.com/abstract=2273470 (access: 26.04.2014).

Czapiewski L., Jewartowski T., Kałdoński M., Mizerka J., 2012, Determinanty natychmiastowych stóp zwrotu za akcji spótek Skarbu Państwa dokonujacych pierwotnych ofert publicznych, researchgate.net (access: 20.11.2013). 
Czapiewski L., Lizińska J., 2014, Performance of Polish IPO Firms: Size and Profitability Effect, Gospodarka Narodowa 1, 53-70.

Jelic, R., Briston R., 2003, Privatisation Initial Public Offerings: The Polish Experience, European Financial Management 9(4), 457-484.

Jewartowski T., Lizińska J., 2012, Short-and Long-Term Performance of Polish IPOs, Emerging Markets Finance and Trade 48(2), 59-75.

Lyn E. O., Zychowicz E. J., 2003, The Performance of New Equity Offerings in Hungary and Poland, Global Finance Journal 14, 181-195.

Ritter J. R., 2003, Differences between European and American IPO markets, European Financial Management 9(4), 421-434.

Joanna Lizińska, Leszek Czapiewski

\section{OCENA KRÓTKO- I DŁUGOOKRESOWEJ REAKCJI RYNKOWEJ TOWARZYSZĄCEJ PIERWOTNYM EMISJOM AKCJI W POLSCE}

Celem badań była ocena reakcji rynkowej następującej po dokonaniu pierwotnych emisji akcji (IPO) przez spółki debiutujące na Giełdzie Papierów Wartościowych w Warszawie w okresie 1996-2010. Zjawisko krótkoterminowego niedoszacowania (underpricingu) i długookresowego przeszacowania cena akcji debiutujących spółek (underperformance) obserwowane było z zastosowaniem różnorodnych podejść badawczych. Reakcja krótkoterminowa była oceniana na podstawie surowych i skorygowanych natychmiastowych stóp zwrotu. Dla długiego okresu, oszacowano ponadnormalne stopy zwrotu skumulowane oraz typu buy-and-hold. Zastosowano kilka podejść eliminacji niewłaściwego wpływu obserwacji skrajnych na wnioskowanie. W procesie oceny reakcji długookresowej, dokonano porównania wyników dla podejścia opartego na notowaniach dziennych, tygodniowych oraz miesięcznych. Zarówno krótkoterminowy underpricing, jak i długookresowe przeszacowanie cen akcji debiutujących spółek pozostawały przez ostatnie lata na polskim rynku kapitałowym zjawiskiem istotnym zarówno statystycznie, jak i ekonomicznie

Słowa kluczowe: pierwotne emisje akcji, IPO, underpricing, underperformance. 